\title{
THIRTIETH ANNUAL MEETING OF THE JAPAN SOCIETY OF HISTOCHEMISTRY AND CYTOCHEMISTRY
}

\author{
October 23-25, 1989
}

\author{
KYOTO \\ President: Dr. Setsuya Fujita \\ Vice-President: Dr. Tsukasa Ashihara \\ - TAKAMATSU AND GOMORI, FIFTIETH \\ YEAR MEMORIAL LECTURE-
}

\section{THE FIFTIETH ANNIVERSARY OF TAKAMATSU-GOMORI}

\author{
TADAO TAKEUCHI \\ Honorary Member of Japan Society of Histochemistry and Cytochemistry \\ and Emeritus Professor of Kumamoto University, Kumamoto 860
}

I considered it a great privilege to be invited to speak about the TakamatsuGomori Fiftieth Anniversary on the occasion of the 30th annual meeting of the Japan Society of Histochemitry and Cytochemistry which was held in Kyoto in 1989. Fifty years ago, I was working with Dr. Takamatsu (1911-1979) at the Manchurian Medical College to histochemically demonstrate phosphatases in tissue cells under normal and pathological conditions in animals and humans. He completed the histochemical method of alkaline phosphatase in1938 (14) and presented it at the annual meeting of the Manchurian Medical Society in the same year. Thereafter he tried to demonstrate different kinds of phosphomonoesterase using various kinds of substrates, phosphamidase, and adenylpyrophosphatase. Takamatsu (15) and Takeuchi and Takamatsu (17) published in German part of the results in Transactiones Societates Pathologicae Japonicae in 1939. In the same year, Dr. Gomori (1904-1957) (5) separately published his method in America. It was in the following year, 1940, that Takamatsu and I saw the journal in which Gomori publisheed his method. We compared both technical subjects with each other and then improved upon them.

In retrospect, the innovations for phosphatase method developed separately and independently were not a coincidence. Rather, there was a scientific atmosphere in the medical fields which encouraged such innovation. There were already two histochmical precursors to detect enzymes, one of which was a silver precipitation technique for phosphatase devised by Robison and his collaborators (1923-1934) (11) who pointed out the important role of phosphatase in the mechanism of bone calcification. The other was a cobalt precipitation (CoS) method for urease by Sen (1934) (12).

Quite early Takamatsu showed interest in abnormal calcification of bone in 
Kashin-Beck's disease which had endemically spread in the north-eastern part of China. Gomori also studied bone diseases before showing interest in histochemistry. It was interesting that both scientists had this common experience and through ticket to enzyme histochemistry.

At any rate, I think we must recognize them as the true founders of the science of Enzyme Histochemistry, in spite of existence of the above mentioned facts. They completely discussed what had to be done in order to get a true reaction for enzymes in which the optimal $\mathrm{pH}$, activators, inhibitors, diffusion of enzyme and its reaction products, intracellular substrate reaction, and negative staining were involved. The true localisation of enzyme reaction products was also discussed at the same time. Their ideas could certainly open the door to a thesaurus of enzyme histochemistry. The principle gave rise to a whole series of histochemical demonstration of enzymes. Since the metal precipitation techniques of various enzymes were thereby found, new principles succesively came into being with the use of various kinds of scientific techniques. The azo-dye coupling principle (Menten et al. , 1944) (9), the hydroxyquinolinFe technique (Friedenwald, 1948) (4), the tetrazolium method (Kan \& Abood, 1948) (6), the thiocholine-Cu method (Koelle \& Friedenwald, 1949) (7), the indoxyl technique (Barnett \& Seligman, 1951) (1), the polarized method (Bèlanger, 1951) (2), the fatty acid-Ca method (Takeuchi et al. , 1953) (19), the fluorescence method (Takeuchi et al., 1954) (18), the marked substrate principle (Takamatsu et al., 1954) (16), the synthetic principle (Takeuchi, 1954) (20), the fluorescence-antibody principle (Marshall et al., 1954) (8), the electron microscopic technique (Sheldon et al., 1955) (13), the substrate film principle (Daoust et al., 1957) (3), and others came one after another.

From these principles and methods, many techniques were produced and many enzymes could be histochemically demonstrated. It outstandingly stimulated an advance of science, particularly in the biological and medical areas.

Applied enzyme histochemistry has also contributed to major parts of histology, embryology, biology, oncology and pathology during the half century since Takeuchi and Takamatsu (1939) first suggested that there is no close relationship between calcification in the caseated focus of tubercle and phosphatase in tuberculosis. A great number of other contributions have added to this body of knowledge.

Above all, a close relationship between structure and function in tissues and cells was clarified. It made a strinking scientific advance in cell biology and medical science. Diagnostic aspects also were utilized by pathologists and oncologists.

The enzyme-labeled antibody methods introduced by Nakane and Pierce (1968) (10), also resulted from enzyme histochemitry and helped make possible important advances in the recent science of hormones, neurotransmitters, and other special proteins. We also know that immunohistochemistry owes much to enzyme histochemistry. In addition, enzyme histochemistry has stimulated other histochemistries. New ideas resulting from these studies have helped produse hybridization histochemistry.

It is fitting for us here on this occasion of their 50th anniversary to again remember the founders of enzyme histochemitry, The late Doctors Takamatsu and Gomori. 


\section{REFERENCES}

1. Barrnett, R. J. and Seligman, A. M.: Science 114; 576, 1951.

2. Bèlanger, L. F.: Proc. Soc. Exper. Biol. \& Med. 77; 266, 1951.

3. Daoust, R. et al.: J. Natl. Cancer Inst. 15; 1447, 1955. Exp. Cell Res. 12; 203, 1957, Ibid. Suppl. 7; 40, 1959.

4. Friedenwald, J. S. et al.: J. Cell Comp. Physiol. 31; 303, 1948.

5. Gomori, G.: Proc. Soc. Exper. Biol. \& Med. 42; 23, 1939.

6. Kan, E. and Abood, L. G.: Science 109; 144, 1949.

7. Koelle, G. H. and Friedenwald, J. B.: Proc. Soc. Exper. Biol. E Med. 70; 617, 1949.

8. Marshall, J. M. et al.: Exper. Cell Res. 6; 240, 1954.

9. Menten, M. L.: Proc. Soc. Exper. Biolog. \& Med. 57; 82, 1944.

10. Nakane, P. K. and Pierce, G. B.: J. Histochem. Cytochem. 14; 929, 1966.

11. Robison, R. et al.: Biochem. J. 17; 286, 1923. Ibid. 18; 740, 1924,. Ibid. 24; 1927, 1930, Ibid. 28; 684, 1934.

12. Sen, P. B.: Indian J. Med. Resech. 18; 79, 1934.

13. Sheldon, H. et al.: Exp. Cell Res. 9; 592, 1955.

14. Takamatsu, H.: Manshu Igaku Zasshi (Jpn. ed.) 31; 34, 1938.

15. Takamatsu, H.: Tr. Soc. Path. Jpn. 29; 492, 1939.

16. Takamatsu, H. et al.: Tr. Soc. Path. Jpn. 43; 204, 1954.

17. Takeuchi, T. and Takamatsu, H.: Ibid. 29; 490, 1939.

18. Takeuchi, T. et al.: Acta Path. Jpn. 4; 277, 1954.

19. Takeuchi, T. et al.: Tokyo Iji Shinshi (Jpn. ed.) 70 (6), 19, 1953. Acta Path. Jpn. 6; 13, 1956.

20. Takeuchi, T.: J. Histochem. Cytochem. 3; 153, 1955. Ibid. 3; 485, Ibid. 6; 208, 1958. 